\title{
FEMALE REPRESENTATION, CORPORATE GOVERNANCE, AND EARNINGS MANAGEMENT IN INDONESIAN NON-FINANCIAL FIRMS
}

\author{
Erick Teofilus Gunawan \\ Sofian \\ Hendra Wijaya \\ S. Patricia Febrina Dwijayanti \\ Widya Mandala Surabaya Catholic University \\ erick@ukwms.ac.id \\ sofian@ukwms.ac.id \\ hendrawijaya@ukwms.ac.id \\ patricia@ukwms.ac.id
}

\author{
A R T I C L E I N F O \\ Article history: \\ Received: 10 October 2021 \\ Revised: 6 December 2021 \\ Accepted: 12 December 2021
}

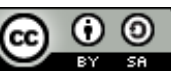

Keywords:

Female Directors, Female Audit

Committee, Internal Corporate

Governance, Earnings Management

DOI:

https://doi.org/10.33508/rima.v4i2.3462

\begin{abstract}
A B S T R A C T
The impact of female directors, managerial ownership, female audit committees, audit committee size, independent commissioners, and board size on earnings management in Indonesian non-financial firms are investigated in this study. Between 2015 and 2017, 291 non-financial enterprises were included in the study's sample. Discretionary accruals are used in this study to assess earnings management. The data were analyzed using multiple regression. This study found that audit committee size negatively affects earnings management; female directors, managerial ownership, female audit committee, independent commissioners, and board size do not affect earnings management. This study contributes to the importance of audit committees as corporate governance mechanisms to reduce earnings management.
\end{abstract}

\section{INTRODUCTION}

The separation of ownership and control can occur in large companies when the owner cannot control the company and needs a manager to manage the company (Yunianto, 2013). Jensen and Meckling (1976) said that the separation of ownership and control between owner and manager could lead to agency conflict. This conflict occurs when the manager, as the agent, has different interests from the owner, often makes decisions that benefit himself (Fama and Jensen, 1983). This article also emphasizes that manager use their knowledge and have more information about the company than the owner, resulting in information asymmetry. The managers use this power to expropriate the owners by making investments that benefit the company. The company can use financial statements (Yunianto, 2013).

The financial statement provides internal and external users with a summary of the company's financial information (Handoyo and Agustianingrun, 2017). According to Griselda and Sjarief (2019), financial statements are the medium through which stakeholders may see the company's performance. If there is a disparity in information between the owner and the manager, they can manipulate earnings on the financial statements to suit 
their needs. According to Kapoor and Goel (2017), difficulties develop when management picks accounting practices to satisfy personal interests and eliminates financial statement openness. Corporate governance is necessary to reduce profits management.

A method and practice for preserving the interests of shareholders are known as corporate governance (Ehikioya, 2009). According to the OECD (2015), corporate governance may assist organizations to achieve their goals, analyze their performance, and provide effective management supervision and accountability to shareholders. Corporate governance is defined by Hassan, Hijazi, and Naser (2017) as the internal and external structures, policies, and practices that command and manage the corporation to protect its stakeholders' interests.

To avoid the impression of earnings management, corporate governance is required. Good company governance may create quality financial reports (Setiawan, 2018). According to Khan, Khidmat, Ullah, and Khan (2019), the role of corporate governance is to ensure the reliability of financial statements. According to Asward and Lina (2015), good corporate governance may be a control technique to reduce agency conflicts. According to Setiawan (2018), Indonesian corporate governance is based on a two-board system, with the board of directors monitoring the board of directors and the board of commissioners controlling the company's operations.

The first thing to think about when it comes to corporate boards of directors is the female gender. Women's traits as managers can lower a company's earnings management. According to Saona, Muro, Martin, and Fuentes (2019), female characters are more risk-averse than males. Hala (2019) discovered that women in higher management impact earnings management in a previous study on the detrimental effect of gender management on earnings management. Harakeh, ElGammal, and Matar (2019) and Kim, Jeong,
Kang, and Lee (2019) conducted studies that support this factor (2017).

On the other hand, Ye, Zhang, and Rezaee (2010) found no earnings quality difference in companies managed by men and women. Peni and Vahamaa (2010) found that this gender issue does not affect earnings management. This research is supported by Lakhal, Aguir, Lakhal, and Malek (2015), who found that the gender of the CEO and CFO did not affect earnings management.

The second factor is related to the company's directors who can reduce earnings management and is one of the internal governances is managerial ownership. One of the mechanisms of agency conflict is managerial ownership. Jensen and Meckling (1976) suggest that managerial ownership can align the interests of company owners and company management. Managerial ownership can reduce the company's earnings management.

Alves (2012), Kang, Leung, Morris, and Gray (2013), Alzoubi (2016), Handoyo and Agustianingrum (2017), Susanto (2016), and Afzal and Habib (2018) support this finding. According to Farouk and Bashir (2017), the contrary is true, which finds that managerial ownership does not affect earnings management. Kumaat (2013) and Lawal, Nwanji, Opeyemi, and Adama (2018), in their research, found that managerial ownership has a positive effect on earnings management.

The next factor related to the board of commissioners and audit committee that can reduce earnings management is the size of the board of commissioners, independent commissioners, and audit committee. Handoyo and Agustianingrum (2017) find that the size of the board of commissioners and the audit committee has a negative effect on earnings management. Kumaat (2013) and Lawal, Nwanji, Opeyemi, and Adama (2018) found that independent commissioners have a negative effect on earnings management. Similar research was 
produced by research conducted by Kapoor and Goel (2017), and Florencea and Susanto (2018) found that the size of the board of commissioners does not affect earnings management. Kumaat (2013) found that independent commissioners positively affect earnings management, and the audit committee does not affect earnings management. Yunianto (2013), Handoyo and Agustianingrum (2017), Lawal et al. (2018), and Griselda and Sjarief (2019) find that independent commissioners do not affect earnings management.

The gender of the audit committee is the next aspect that might worsen a company's profit management. Women's qualities on audit committees have the potential to worsen profit management. The result is supported by research conducted by Thiruvadi and Huang (2011), Qi and Tian (2012), Salleh, Hashim, Mohamad (2012), Susanto (2016), and Florencea and Susanto (2018). Research conducted by Loualalen, Khemakhem, and Fontaine (2015) and Abdullah and Ismail (2016) found that gender on the audit committee did not affect profit management. Kusumaningtyas, Chariri, and Yuyetta (2019) also found that the gender of the audit committee did not affect profit management.

Previous research on the effect of female directors, management ownership, women's audit committees, audit committees, independent commissioners, and board sizes has yielded mixed findings. Profit management's Commissioner. The proportion of women in top executive roles has increased. (Grant Thornton, 2020). The second factor is Indonesia's kinship system, which allows relatives to serve on boards of commissioners and directors (Murhadi, 2009).

The study's first goal was to analyze the influence of female directors on profit management. The second goal is to analyze the influence of managerial ownership on profit management. The third and fourth objectives are to analyze the influence of women's audit committees and audit committees on profit management. The fifth and sixth objectives are to analyze the influence of independent commissioners and the size of the board of commissioners on profit management.

\section{LITERATURE REVIEW AND HYPOTHESIS DEVELOPMENT}

Jensen and Meckling (1976) created the agency theory. They use the metaphor of a contract between one or more people (the principal or owner(s)) and another person (the agent or manager) to execute service on their behalf, which includes transferring certain decision-making authority to the agent. An agency problem arose when the owner delegated some operational and strategic management tasks and obligations to the manager, hoping that the manager's judgments would optimize company value. However, sometimes a manager has different goals or desires from the owner, and it is difficult for the owner to verify the manager does according to what the owner wants, so agency conflict often arises on both parties. The other cause of agency conflict between owner and manager is the problem of risk sharing that arises when owner and manager have different risk preferences (Eisenhardt, 1989).

Information asymmetry, moral hazard, and adverse selection are some of the challenges related to agency theory in terms of the agency relationship. Information asymmetry occurs when the manager has better information and abilities than an owner (Kholmurodova, 2009). Every day managers are in the firm, understand every activity in the firm, and have a right to manage the firm's resources to have better information about the firm's operation than the owner. The manager can use this information to take advantage of the firm.

To avoid agency problems that occur to the owner and manager, the owner needs to monitor agents' behavior and resulting costs for the firm (monitoring costs). Therefore, agency problem creates agency cost in a firm because it is impossible for the owner and agent at zero cost to ensure that the agent 
will make optimal decisions from the owner's viewpoint. In terms of using the firm's resources, the manager will not always have the same perspective as the owner, and sometimes it will harm the owner if the owner is indirectly involved in firm management.

Thus, the owner must limit the manager's actions by providing incentives (bonding costs) to harm the owner. The other cost from the difference of interest between owner and manager in terms of the agency relationship, they named this cost as the "residual loss" (Jensen and Meckling, 1976). They define agency costs as the total of the principal's monitoring expenses, the agent's bonding expenses, and the residual loss.

\section{Female Directors and Earnings Management}

Female directors are the leaders of companies that have female gender. Female directors can reduce profit management caused by some characteristics; women are more risk-averse than men to avoid risk in profit management and women. Work can be seen as a source of self-development by more individuals, whereas males are more concerned with advancement and remuneration (Gavious, 2012).

Women are more likely than males to have worse quality in generating financial statements and smaller profit management, according to Saona, Muro, Martin, and Fuentes (2019), because women are more risk-averse and cautious than men. According to Lakhal et al. (2015), women have a favorable influence on corporate governance since they exhibit more ethical and conservative tendencies than males. Men may see a decline in profit management as a result of this.

Including women among the firm, executives imply that the organization's leadership is gender diverse, preventing specific individuals or groups from dominating the process. Making a decision (Lakhal et al., 2015). Hala (2019) and Harakeh, El-Gammal, and Matar (2019) found that women are in managerial positions. The top tier can reduce profit management. Kim, Jeong, Kang, and Lee (2017) also found that female directors negatively influence profit management.

$\mathrm{H} 1$ : Female directors negatively affect profit management

\section{Managerial Ownership and Earnings Management}

Managerial ownership is shares owned by a company's management. Jensen and Meckling (1976) fattened that managerial ownership was one of the mechanisms of agency conflict. Managerial ownership can decrease profit management by aligning the interests of the company's management with those of the shareholders. This mechanism was supported by Warfield, Wild, and Wild (1995), who argued that managerial ownership is a mechanism to limit the opportunistic behavior of managers that impact the decline of profit management.

Kang, Leung, Morris, and Gray (2013) argue that high managerial ownership can reduce conflicts between managers and shareholders, impacting low-profit management. This result is supported by Alves's (2012) research, which found that managerial ownership negatively affects profit management. Similar research results obtained by Afzal and Habib (2018) also found that managerial ownership negatively affects profit management. Susanto (2016) also supported it, who found that under managerial ownership negatively affects profit management.

H2: Managerial ownership negatively affects profit management

\section{Female Audit Committee and Earnings Management}

The audit committee is formed and responsible on the company's board of commissioners (POJK No. 55 of 2015). Because women are more ethical and cautious than males, women's audit committees can help to decrease profit 
management (Lakhal et al., 2015). Saona, Muro, Martin, and Fuentes (2019) and Gavious (2012) suggest that women are more risky and conservative. Salleh, Hashim, and Mohamad (2012) suggest that women can give different perspectives and opinions to the discussion, have high moral standards, and be more trustworthy.

The female representation, according to Salleh, Hashim, and Mohamad (2012), can increase the committee's function and efficiency. Sun et al. (2011) suggest that members of the audit committee who have female gender will act against profit management because they believe more than profit management is unethical. This suggestion is supported by Zalata, Tauringana, and Tingbani (2017), Salleh, Hashim, Mohamad (2012), Thiruvadi, and Huang (2011), which found that the audit committee was female. It can reduce profit management. Florencea and Susanto (2018) and Susanto (2016) also found that women's audit committees could reduce profit management at manufacturing companies in Indonesia.

H3: Women's audit committee negatively affects profit management

\section{Audit Committee and Earnings Management}

An audit committee is formed and responsible to the board of commissioners whose sole duty is to investigate the company's financial information in compliance with the relevant laws and regulations with the company's activities (POJK No. 55 of 2015). Audit committees can reduce profit management because the audit committee can increase transparency and disclosure of financial statements (Handoyo and Agustianingrum, 2017). Chen, Duh, Shiue (2008) stated that the audit committee is a monitoring mechanism tasked with protecting the importance of shareholders by monitoring the financial reporting process and assessing the feasibility of accounting treatment on company transactions. Handoyo and Agustianingrum (2017), in their research, found that the audit committee can run profit management. It was also supported by Alzoubi (2019), who found that the existence of an audit committee can degrade profit management.

H4: Komite audit women negatively affect profit management

\section{Independent Commissioner and Earnings Management}

An independent commissioner of a company comes from outside. He has no part of the company directly or indirectly with the company, is not affiliated with the board of commissioners, members of the board of directors, or the company's main shareholder. The independent Commissioner has no business relationship with planning, leading, controlling, and supervising the company (POJK No. 33). A larger independent commissioner can reduce profit management because the proportion of independent commissioners can contribute to quality financial statements (Handoyo and Agustianingrum,2017). It is also supported by Kapoor and Goel (2017), who argue that the existence of independent commissioners is to improve the transparency and integrity of financial statements.

Yunianto (2013) stated that independent parties could protect the interests of the company's external parties to the Commissioner. Griselda and Sjarief (2019) stated that the role of independent commissioners is to oversee and advise the board of directors, as well as to guarantee that good corporate governance is implemented. It can reduce profit management practices. Sraheen and Daoud (2018) found that independent commissioners negatively influence profit management. It was also supported by research conducted by Chen, Cheng, and Wang (2015), which found that independent commissioners negatively influence profit management.

H5: Independent commissioners negatively affect profit management 


\section{Board Size and Earnings Management}

The size of the board is the number of commissioners in a company. The Commissioner must supervise the company's management (POJK No. 33). Board size can reduce profit management because more boards in a company can be more effective in carrying out monitoring functions in management (Hassan, Hijazi, and Naser, 2017). It is also supported by Mukhtaruddin, Zuryati, Robiana, and Saftiana (2018), who suggest that the size of the board can be increasingly complex monitoring as well. Khan, Khidmat, Ullah, and Khan (2019) suggest that the larger the size of the board, the richer the knowledge and experience comes from various sources.

Afzal and Habib (2018) argued that the company's decisions could be taken better because the larger the size of the board can oversee management more effectively. Afzal and Habib (2018) also found that the size of the board negatively affects profit management. Zehri and Zgarni (2020) found that increasingly larger board sizes effectively reduce profit management. It was also supported by Kusumaningtyas, Chariri, and Yuyetta (2019), who found that the number of board of commissioners negatively affects profit management.

H6: The size of the board of commissioners negatively affects profit management

\section{RESEARCH METHOD}

During 2015-2017, this study employed secondary data in imbalanced panel data. The Indonesian Stock Exchange (IDX) obtained annual reports and financial statements. The population is non-financial firms listed on the IDX. Purposive sampling was used to collect the samples with the following criteria: (1) The firm listed in IDX during the 2015-2017 periods; (2) The financial statement listed in rupiahs; (3) The firms have complete data for this research. The total samples obtained are 287 companies and 826 observations. The sample selection criteria of this research showed in Table 1.
Table 1. Sample Selection Criteria

\begin{tabular}{|c|c|}
\hline Criteria & Total \\
\hline $\begin{array}{l}\text { Population: non- } \\
\text { financial firms listed on } \\
\text { the IDX (2015-2017) }\end{array}$ & 520 \\
\hline \multicolumn{2}{|l|}{$\begin{array}{l}\text { The firms that do not } \\
\text { meet the criteria of } \\
\text { purposive sampling: }\end{array}$} \\
\hline $\begin{array}{l}\text { (1) The firm listed in } \\
\text { IDX (2015-2017) }\end{array}$ & 5 \\
\hline $\begin{array}{l}\text { (2) The firm, data } \\
\text { complete }\end{array}$ & $\begin{array}{c}8 \\
196\end{array}$ \\
\hline $\begin{array}{l}\text { (30 The financial } \\
\text { statement listed in } \\
\text { rupiahs }\end{array}$ & \\
\hline $\begin{array}{l}\text { Firms that satisfy the } \\
\text { criteria }\end{array}$ & 311 \\
\hline Observation period & 3 \\
\hline Total observation & 933 \\
\hline Outlier & 107 \\
\hline Total sample & 826 \\
\hline
\end{tabular}

The following model was used to evaluate the data: panel data regression and multiple linear regressions:

$\mathrm{EM}_{\mathrm{it}}=\alpha+\beta_{1} \mathrm{FD}_{\mathrm{it}}+\beta_{2} \mathrm{MO}_{\mathrm{it}}+\beta_{3} \mathrm{FA}_{\mathrm{it}}+\beta_{4} \mathrm{NA}_{\mathrm{it}}$ $+\beta_{5} \mathrm{IC}_{\mathrm{it}}+\beta_{6} \mathrm{BS}_{\mathrm{it}}+\beta_{7} \mathrm{PR}_{\mathrm{it}}+\beta_{8} \mathrm{LV}_{\mathrm{it}}+\beta_{9} \mathrm{SZ}_{\mathrm{it}}+\varepsilon$

\section{Description:}

EM: Earnings Management

FD: Female Directors

MO: Managerial Ownership

FA: Female Proportion in Audit Committee NA: Audit Committee

IC: Independent Commissioner

BS: Board Size

PR: Profitability

LV: Leverage

SZ: Firm Size

Earnings management (EM) is the dependent variable in this research. This 
study uses the Modified Jones Model to assess earnings management through discretionary accruals. The independent variables in this research are female directors (FD), independent commissioner (IC), managerial ownership (MO), institutional ownership (IO), and leverage (LV). FD was measured by the number of female directors divided by the total directors. IC is the number of independent commissioners divided by the total board of commissioners. $\mathrm{MO}$ is the number of shares held by the director of the firms divided by the number of shares; $\mathrm{IO}$ is the number of shares held by institutional ownership divided by the number of shares; LV is the total debt divided by the total asset.

Three control variables are in this study are profitability (PR), sales growth (SG), firm size (SZ), and state ownership (SO). The return on asset measured $\mathrm{PR}$, net income divided by the total asset. SG was measured by the difference between sales in the current year and the previous year divided by sales in the previous year. SZ was measured by market capitalization, the stock price multiplied by outstanding shares. SO was measured by dummy variables; one indicates state ownership and zeroes otherwise.

The equation of variables showed in Table 2.
Table 2. Research Variables

\begin{tabular}{|c|c|c|}
\hline VAR & EQUATION & SOURCES \\
\hline EM & $\begin{array}{l}\text { Discretionary } \\
\text { Accruals } \\
\text { (Modified Jones } \\
\text { Model) }\end{array}$ & $\begin{array}{l}\text { Alzoubi (2016) } \\
\text { Handoyo and } \\
\text { Agustianingru } \\
\text { m (2017) }\end{array}$ \\
\hline FD & $\begin{array}{l}\text { Number of Female } \\
\text { Directors } \\
\text { Total Directors }\end{array}$ & Gavious (2012) \\
\hline $\mathrm{MO}$ & $\begin{array}{l}\text { Managerial } \\
\text { Ownership }\end{array}$ & $\begin{array}{l}\text { Handoyo and } \\
\text { Agustianingru } \\
\mathrm{m}(2017)\end{array}$ \\
\hline FA & $\begin{array}{l}\text { Female Audit } \\
\text { Committee } \\
\text { Number of Audit } \\
\text { Committee }\end{array}$ & Gavious (2012) \\
\hline NA & $\begin{array}{l}\text { Number of Audit } \\
\text { Committee }\end{array}$ & $\begin{array}{l}\text { Handayani } \\
(2017)\end{array}$ \\
\hline IC & $\begin{array}{l}\text { Number of } \\
\text { Independent } \\
\text { Commissioner } \\
\text { Total } \\
\text { Commissioner }\end{array}$ & $\begin{array}{l}\text { Handoyo and } \\
\text { Agustianingru } \\
\text { m (2017) } \\
\text { Kapoor and } \\
\text { Goel (2017) }\end{array}$ \\
\hline BS & Board Size & $\begin{array}{l}\text { Ehikioya (2009) } \\
\text { Lakhal et al. } \\
(2015)\end{array}$ \\
\hline PR & $\begin{array}{l}\text { Net Income } \\
\text { Total Assets }\end{array}$ & $\begin{array}{l}\text { Lakhal et al. } \\
\text { (2015) }\end{array}$ \\
\hline LV & $\begin{array}{l}\text { Total Debt } \\
\text { Total Assets }\end{array}$ & $\begin{array}{l}\text { Lakhal et al. } \\
\text { (2015) }\end{array}$ \\
\hline SZ & $\begin{array}{l}\text { Logarithm (Total } \\
\text { Asset) }\end{array}$ & $\begin{array}{l}\text { Ehikioya (2009) } \\
\text { Alzoubi (2016) }\end{array}$ \\
\hline
\end{tabular}

\section{RESULT AND DISCUSSION}

This study analyzes the effect of female representation and internal governance mechanisms on earnings management.

Table 3. Descriptive Statistics

\begin{tabular}{|l|c|c|c|c|}
\hline & Mean & Std.dev & Max & Min \\
\hline Earnings Management (EM) & 0.0127 & 0.0740 & 0.2815 & -0.2378 \\
\hline Female Directors (FD) & 0.1438 & 0.1888 & 1.0000 & 0.0000 \\
\hline Managerial Ownership (MO) & 0.0202 & 0.0730 & 0.6828 & 0.0000 \\
\hline Female Audit Committee (FA) & 0.1738 & 0.2375 & 1.0000 & 0.0000 \\
\hline Audit Committee (NA) & 3.0266 & 0.2983 & 4.0000 & 2.0000 \\
\hline Independent Commissioner (IC) & 0.4030 & 0.0962 & 0.7500 & 0.2000 \\
\hline Board Size (BS) & 4.1780 & 1.6627 & 10.0000 & 2.0000 \\
\hline Profitability (PR) & 0.0314 & 0.0682 & 0.2731 & -0.2099 \\
\hline
\end{tabular}




\begin{tabular}{|l|c|c|c|c|}
\hline & Mean & Std.dev & Max & Min \\
\hline Lev (LV) & 0.4480 & 0.2095 & 1.0504 & 0.0076 \\
\hline Size (SZ) & 12.3902 & 0.6947 & 14.2206 & 10.3209 \\
\hline Size (In Million Rp) & $7,595,853.6895$ & $13,826,626.5499$ & $166,173,000.0000$ & $20,936.6191$ \\
\hline
\end{tabular}

Table 3 shows the descriptive statistics: mean, standard deviation, maximum, and minimum. The mean of the EM was 0.0127, the mean of the FD was 0.1438 . It indicated that $14.38 \%$ of the board of directors are female. The mean of the MO was 0.0202. It indicated that the mean of managerial ownership in the firm is $2.02 \%$. The mean of the FA was 0.1738. It indicated that the proportion of females in the audit committee is $17.38 \%$. The mean of the NA was 3.0266. It indicated that the mean of the audit committee is 3 in a firm. The mean of the IC was 0.4030 . It indicated that $40.30 \%$ of the board of the Commissioner are independent. The mean of BS was 4.1780, indicating that the mean board commissioner size is 4 in a firm.

The mean of the PR was 0.0314 (Table 3). It means that the firm obtains the net income $3.14 \%$ from the total asset. The mean of the LV was 0.4480 , which means that the firm finances its assets with $44.80 \%$ debt. The mean of the SZ was 12.3902 means that the total asset's mean was 7,595,854 million rupiahs.

Tabel 4. Correlation Analysis

\begin{tabular}{|l|c|c|c|c|c|c|c|c|c|c|}
\hline & EM & FD & MO & FA & NA & IC & BS & PR & LV & SZ \\
\hline EM & 1.00 & -0.0152 & -0.0450 & 0.0360 & $-0.1182^{* *}$ & 0.0085 & -0.0238 & $0.2222^{* *}$ & $-0.1242^{* *}$ & -0.0376 \\
\hline FD & & 1.0000 & -0.0083 & 0.0519 & -0.0605 & -0.0413 & -0.0018 & 0.0194 & $-0.1534^{* *}$ & $-0.0861^{*}$ \\
\hline MO & & & 1.0000 & $0.0694^{*}$ & 0.0081 & -0.0368 & $-0.1258^{* *}$ & -0.0405 & -0.0104 & $-0.1411^{* *}$ \\
\hline FA & & & & 1.0000 & -0.0184 & -0.0493 & $-0.0963^{* *}$ & 0.0065 & $-0.0833^{*}$ & $-0.1034^{* *}$ \\
\hline NA & & & & & 1.0000 & 0.0313 & $0.1542^{* *}$ & $0.0932^{* *}$ & 0.0213 & $0.2045^{* *}$ \\
\hline IC & & & & & & 1.0000 & $-0.1039^{* *}$ & -0.0627 & 0.0324 & 0.0006 \\
\hline BS & & & & & & & 1.0000 & $0.1338^{* *}$ & $0.0848^{*}$ & $0.5449^{* *}$ \\
\hline PR & & & & & & & & 1.0000 & $-0.2797^{* *}$ & $0.2076^{* *}$ \\
\hline LV & & & & & & & & & 1.0000 & $0.1504^{* *}$ \\
\hline SZ & & & & & & & & & & 1.0000 \\
\hline
\end{tabular}

Table 4 showed that the correlation of FD to MO was -0.0083 , FD to FA was 0.0519 , FD to NA was -0.0605 , FD to IC was -0.0413 , FD to BS was -0. 0018, FD to PR was 0.0194, FD to LV was -0.1534, and FD to SZ was 0.0861 . The correlation between $\mathrm{MO}$ to FA was $0.0694, \mathrm{MO}$ to NA was $0.0081, \mathrm{MO}$ to IC was $-0.0368, \mathrm{MO}$ to BS was $-0.1258, \mathrm{MO}$ to PR was -0.0405 , MO to LV was -0.0104 , and $\mathrm{MO}$ to SZ was -0.1411. The correlation between FA to NA was -0.0184, FA to IC was $-0.0493, \mathrm{FA}$ to BS was $-0.0963, \mathrm{FA}$ to PR was 0.0065 , FA to LV was -0.0833 , and FA to SZ was -0.1034 . The correlation between NA to
IC was 0.0313 , NA to BS was 0.1542, NA to PR was 0.0932 , NA to LV was 0.0213 , NA to SZ was 0.2045 . The correlation between IC to BS was -0.1039 , IC to PR was -0.0627 , IC to LV was 0.0324 , and IC to SZ was 0.0006 . The correlation between BS to PR was 0.1338 , BS to $L V$ was 0.0848 , and BS to SZ was 0.5449 . The correlation between PR to LV was 0.2797, and PR to SZ was 0.2076. The correlation between LV to SZ was 0.1504 . The result showed no multicollinearity between the variables. 
Table 5. Regression Results

\begin{tabular}{|l|c|c|c|c|}
\hline \multicolumn{1}{|c|}{ Variable } & Coefficent & Std. Error & t-Statistic & Sig \\
\hline Female Directors (FD) & -0.0163 & 0.0155 & -1.0507 & 0.2937 \\
\hline Managerial Ownership (MO) & -0.0452 & 0.0155 & -1.0507 & 0.1440 \\
\hline Female Audit Committee (FA) & 0.0088 & 0.0309 & -1.4624 & 0.3894 \\
\hline Audit Committee (NA) & -0.0321 & 0.0102 & 0.8611 & 0.0029 \\
\hline $\begin{array}{l}\text { Independent Commissioner } \\
\text { (IC) }\end{array}$ & 0.0208 & 0.0107 & -2.9858 & 0.4221 \\
\hline Board Size (BS) & & & 0.8031 & 0.9685 \\
\hline Profitability (PR) & 0.0000 & 0.0259 & 5.2761 & 0.0000 \\
\hline Lev (LV) & 0.2519 & 0.0477 & -1.4256 & 0.1544 \\
\hline Size (SZ) & -0.0188 & 0.0132 & -1.2741 & 0.2030 \\
\hline R-Squared & -0.0063 & 0.0050 & 0.0795 \\
\hline Adj R-Squared & \multicolumn{5}{|c|}{0.0693} \\
\hline F-Statistic & \multicolumn{5}{|c|}{0.0000} \\
\hline Sig & \multicolumn{5}{|c|}{} \\
\hline
\end{tabular}

Table 5 showed that the female directors, managerial ownership, female audit committee, independent Commissioner, and board size did not affect earnings management, so this research's first, second, third, fifth, and sixth hypothesis is rejected. This study also showed that the audit committee had a negative effect on earnings management, so the fourth hypothesis of this research is not rejected.

\section{Discussion}

Female Directors and Earnings Management

This study showed that female directors did not affect profit management. The gender of female directors does not influence profit management. Descriptive statistics of the study also show that the average proportion of female directors in companies is still small and only by $14.38 \%$ so that female directors existing companies. It still cannot reduce profit management. The study also showed no difference in ethical values and risk appetite between men and women in Indonesia. This result was supported by Ye et al. (2010), which also found that the gender of the director did not affect the company's profit management. The results contradict research conducted by Kim, Jeong, Kang, and Lee (2017), Hala
(2019), Harakeh, El-Gammal, and Matar (2019), which found that the director Women negatively affect profit management.

Managerial Ownership and Earnings Management

This study shows that managerial ownership does not affect profit management. Profit management is not affected by managerial ownership because the managerial ownership in Indonesia is still very small. It can also be seen in this study's descriptive statistics, which show that the average managerial ownership is only $2.02 \%$. The results of this study are supported by research conducted by Yunianto (2013). The results contradict the research conducted by Alves (2012), Kang et al. (2013), Alzoubi (2016), who found that managerial ownership negatively affects profit management.

\section{Female Audit Committee and Earnings Management}

This study showed that the women's audit committee did not affect profit management. Profit management is not affected by the gender of the company's audit committee. Descriptive statistics of the study also show that the average proportion 
of female audit committees in companies is still small, and only $17.38 \%$ so that the audit committee is female. Existing companies are still unable to reduce profit management. The study also showed that the ethical values and risk appetites between men and women in Indonesia are no different. This result was supported by Loualalen et al. (2015) and Abdullah and Ismail (2016), who also found that the gender of the audit committee did not affect the company's profit management. The results contradict research conducted by Thiruvadi and Huang (2011), Qi and Tian (2012), and Salleh, Hashim, Mohamad (2012), which found that female directors negatively influence management profit.

\section{Audit Committee and Earnings Management}

This study shows that the audit committee negatively affects profit management. The existence of an audit committee measured using the size of the audit committee can reduce the company's profit management. The existence of an audit committee can be an effective supervisory mechanism for company management in Indonesia. Handayani (2017) found that the audit committee is a controlling mechanism in providing financial statements.

This result was supported by Handoyo and Agustianingrum (2017), who conducted research on manufacturing companies in Indonesia and found that the audit committee negatively affects profit management. Handoyo and Agustianingrum (2017) also stated that the disclosure of more transparent financial statements increased with the audit committee. These results contradict Kumaat (2013), which found that the size of the audit committee did not affect profit management.

\section{Independent Commissioner and Earnings Management}

This study showed that independent commissioners did not affect profit management. This phenomenon can happen due to the existence of independent commissioners in Indonesia's companies to complete the regulations that have been set. It was also supported by Yunianto (2013), who stated that the motivation for the appointment of independent commissioners only to meet the regulations were established not to strengthen supervision on company management; this results supported by Yunianto (2013), Lawal et al. (2018) and Griselda and Sjarief (2019). The results contradict Chen, Cheng, and Wang (2015) found that independent commissioners negatively influence profit management.

\section{Board Size and Earnings Management}

In this study, the size of the board of commissioners did not affect profit management. The profit management is not affected by the size of the board of commissioners because, in Indonesia, it is still possible to have a family relationship between the board of commissioners and the company's board of directors (Murhadi, 2009). The family relationship between the board of commissioners and the company's board of directors leads to reduced effectiveness of the supervisory function of the board of commissioners. Mukhtaruddin, Zuryati, Robiani, and Saftiana (2018) stated that several company commissioners hold important positions in other companies that can cause no effectiveness in overseeing the company. The results of this study are supported by research conducted by Kapoor and Goel (2017) and Florencea and Susanto (2018). This result contradicts Handoyo and Agustianingrum (2017), which found that the size of the study. The board of commissioners negatively affects profit management.

\section{CONCLUSIONS}

Based on previous analysis and discussions, the conclusions were that female directors, managerial ownership, women's audit committees, independent commissioners, and board sizes did not 
reduce the company's profit management. In addition, this study concludes that the audit committee reduces the company's profit management. The audit committee is an important committee to get attention as a form of supervision of corporate management decision making, especially in the selection of accounting methods in the manufacture of financial statements can thus reduce profit management. Supervision of management decisionmaking is important to get attention concerning agency conflicts arising from the separation of owners and management of the company.

The only compatibility of the study is that this study only analyzed the impact of gender on directors and audit committees, managerial ownership, audit committee size, board size, and independent Commissioner of profit management. Further research can analyze the characteristics of the board of commissioners, audit committee, and board of directors more deeply, such as educational background, age, and length of work. Subsequent research can also analyze the characteristic influence of the board of commissioners, audit committees, and board of directors on real profit management.

\section{REFERENCES}

Abdullah, S. N., \& Ismail, K. N. I. K. (2016). Women directors, family ownership, and earnings management in Malaysia. Asian Review of Accounting, 24(4), 525550. https://doi.org/10.1108/ARA-072015-0067

Afzal, M., \& Habib, M. D. (2018). Corporate governance and earnings management: a model and empirical investigation from Karachi Stock Exchange. Journal of Finance \& Economics Research, 3(2), 5167.

Alzoubi, E. S. S. (2016). Ownership structure and earnings management: Evidence from Jordan. International Journal of
Accounting and Information

Management, 24(2), 135-161. https:// doi.org/10.1108/IJAIM-062015-0031

Alves, Sandra, Ownership Structure and Earnings Management: Evidence from Portugal, Australasian Accounting, Business, and Finance Journal, 6(1), 2012, 57-74.

Asward, I., \& Lina, L. (2015). Pengaruh Mekanisme Corporate Governance terhadap Manajemen Laba dengan Pendekatan Conditional Revenue Model. Jurnal Manajemen Teknologi, 14(1), 15-34. https:// doi.org/10.12695/jmt.2015.14.1 .2

Chen, X., Cheng, Q., \& Wang, X. (2015). Does increased board independence reduce earnings management? Evidence from recent regulatory reforms. Review of Accounting Studies, 20(2), 899-933. https:// doi.org/10.1007/s11142-0159316-0

Chen, J., Duh, R. R., \& Shiue, F. N. (2008). The effect of audit committees on earningsreturn association: evidence from foreign registrants in the United States. Corporate Governance: An International Review, 16(1), 32-40.

Eisenhardt, K. M. (1989). Agency theory: An assessment and review. Academy of management review, 14(1), 57-74.

Ehikioya, B. I. (2009). Corporate governance structure and firm performance in developing economies: Evidence from Nigeria. Corporate Governance: The International Journal of Business in Society, 9(3), 231-243. https:// doi.org/10.1108/147207009109 64307

Fama, E. F., \& Jensen, M. C. (1983). Separation of Ownership and Control Separation of Ownership and Control. Journal of Law and Economics, 26(2), 301-325. 
https://doi.org/10.1086/467037

Farouk, M. A., \& Bashir, N. M. (2017). Ownership structure and earnings management of listed conglomerates in Nigeria. Indian-Pacific Journal of Accounting and Finance, 1(4), 42-54.

Florencea, N., \& Susanto, Y. K. (2019). Audit Committee: Woman, Experience, Education on Earnings Management. 73(Aicar 2018), 17-21. https://doi.org/10.2991/aicar18.2019.5

Gavious, I., Segev, E., \& Yosef, R. (2012). Female directors and earnings management in high-technology firms. Pacific Accounting Review, 24(1), 4-32. https://doi.org/10.1108/011405812112 21533

Grant Thorton. (2020). Woman in Business 2020: Putting the Blueprint into Action.

Griselda, A., \& Sjarief, J. (2019). Pengaruh Ukuran Perusahaan dan Corporate Governance terhadap Earnings Management serta Dampaknya terhadap Earnings Quality. Jurnal Akuntansi, 13(2), 143-168. https://doi.org/https://doi.org/10.25 170/jara.v13i2

Hala, G. S. (2019). Women on boards and earnings management: What really matters? Jurnal Keuangan Dan Perbankan, 23(4), 566-578. https://doi.org/10.26905/jkdp.v23i4.3 439

Handoyo, S., \& Agustianingrum, W. B. (2017). GCG Role and Audit Quality in Reducing Earnings Management Action in Indonesian Manufacturing Firms. Jurnal Keuangan Dan Perbankan, 21(3), 436-445.

https://doi.org/10.26905/jkdp.v21i3.6 73

Harakeh, M., El-Gammal, W., \& Matar, G. (2019). Female directors, earnings management, and CEO incentive compensation: UK evidence. Research in
International Business and Finance, 50(April), 153-170. https://doi.org/10.1016/j.ribaf.2019.05. 001

Hassan, Y., Hijazi, R., \& Naser, K. (2017). Does audit committee substitute or complement other corporate governance mechanisms: Evidence from an emerging economy. Managerial Auditing Journal, 32(7), 658-681. https:// doi.org/10.1108/MAJ-08-20161423

Jensen, M. C., \& Meckling, W. H. (1976). Theory of The Firm: Managerial Behavior, Agency Costs, and Ownership Structure. Journal of Financial Economics, 3(1976), 305-360.

Kang H; Leung S; Gray SJ; Morris RD, 2013, 'Corporate governance and earnings management: An Australian perspective', Corporate Ownership and Control, vol. 10, pp. 95 113, http:/ / dx.doi.org/10.22495/cocv1 0i3art8

Kapoor, N., \& Goel, S. (2017). Board Characteristics, Firm Profitability and Earnings Management: Evidence from India. Australian Accounting Review, 27(2), 180-194. https://doi.org/10.1111/auar.12144

Khan, M. A., Khidmat, W. Bin, Ullah, F., \& Khan, N. U. (2019). Corporate Governance and Earnings Management: The Role of Board of Directors. Sarhad Journal of Management Sciences, 5(2), 317-342.

Kholmurodova, A. (2009). Family ownership and firm performance. M.Sc. Thesis in Business Administration (Finance and International Business), (December).

Kim, H. A., Jeong, S. W., Kang, T., \& Lee, D. (2017). Does the Presence of Female Executives Curb Earnings Management? Evidence from Korea. Australian Accounting Review, 27(4), 494-506. 
https://doi.org/10.1111/auar.12169

Kumaat, L. C. (2013). Corporate Governance dan struktur kepemilikan terhadap manajemen laba dan kinerja keuangan. Jurnal Keuangan dan Perbankan, 17(1), 11-20.

Kusumaningtyas, M., Chariri, A., \& Yuyetta, E. N. A. (2019). Board Of Commissioners, Audit Committee Gender, Institutional Ownership, and Earnings Management. 102 (Icaf), 103108. https://doi.org/10.2991/icaf19.2019.17

Lakhal, F., Aguir, A., Lakhal, N., \& Malek, A. (2015). Do women on boards and in top management reduce earnings management? Evidence in France. Journal of Applied Business Research, 31(3), 1107-1118. https://doi.org/10.19030/jabr.v31i3.92 36

Lawal, A. I., Nwanji, T. I., Opeyemi, O. O., \& Adama, I. J. (2018). Can corporate governance mechanisms deter earnings management? Evidence from firms listed on the Nigerian Stock Exchange. Aestimatio: The IEB International Journal of Finance, (17), 220-233.

Loualalen, L., Khemakhem, H., \& Fontaine, R. (2015). The Impact of Audit Committee Characteristics on Earnings Management: A Canadian Case Study. Case Studies in Business and Management, 2(1), 68-86.

Murhadi, W. R. (2009). Studi Pengaruh Good Corporate Governance Terhadap Praktik Earnings Management pada Perusahaan Terdaftar di PT Bursa Efek Indonesia. Jurnal Manajemen Dan Wirausaha, 11(1), 1-10. https://doi.org/10.9744/jmk.11.1.pp.110

OECD. (2015). G20/OECD Principles of Corporate Governance. OECD Publishing, https://doi.org/http://dx.doi.org/10. 1787/9789264236882-en

Direksi dan Dewan Komisaris Emiten atau Perusahaan Publik, Pub. L. No. 33/POJK.04/2014, https://www.ojk.go.id/id/kanal/pasa r-modal/regulasi/peraturanojk/default.aspx (2014).

Pembentukan Dan Pedoman Pelaksanaan Kerja Komite Audit, Pub. L. No. 55 /POJK.04/2015, https://www.ojk.go.id/id/kanal/pasa r-modal/regulasi/peraturanojk/default.aspx 1 (2015).

Peni, E., \& Vähämaa, S. (2010). Female executives and earnings management. Managerial Finance, 36(7), 629-645. https:// doi.org/10.1108/030743510110 50343

Qi, B., \& Tian, G. (2012). The Impact Of Audit Committees Personal Characteristics On Earnings Management: Evidence From China. Journal of Applied Business Research (JABR), 28(6), 1331-1344. https:// doi.org/10.19030/jabr.v28i6.73 47

Salleh, Z., Hashim, H. A., \& Mohamad, N. R. (2012). Accrual quality: The presence of women directors on audit committee boards. Corporate Ownership and Control, $\quad 10(1 \quad \mathrm{H}), \quad 675-680$. https:// doi.org/10.22495/cocv10i1c7ar t3

Saona, P., Muro, L., San Martín, P., \& BaierFuentes, H. (2019). Board of directors gender diversity and its impact on earnings management: An empirical analysis for select European firms. Technological and Economic Development of Economy, 25(4), 634663.

https:// doi.org/10.3846/tede.2019.938 1

Setiawan, D. (2018). Karakteristik dewan komisaris dan manajemen laba: bukti pada peristiwa penawaran saham 
perdana. Jurnal Siasat Bisnis, 22(2), 164181.

https://doi.org/10.20885/jsb.vol22.iss2 .art4

Al-Deen Al-Sraheen, D., \& Ahmad Al Daoud, K. (2018). Does the presence of independent directors reduce the practices of earnings management? The moderating role of family ownership concentration. Ekonomski pregled, 69(6), 638-654.

Sun, J., Liu, G., \& Lan, G. (2011). Does Female Directorship on Independent Audit Committees Constrain Earnings Management? Journal of Business Ethics, 99(3), 369-382. https://doi.org/10.1007/s10551-0100657-0

Susanto, Y. K. (2016). the Effect of Audit Committees and Corporate Governance on Earnings Management: Evidence From Indonesia Manufacturing Industry. International Journal of Business, Economics, and Law, 10(1), 32-37.

Thiruvadi, S., \& Huang, H. W. (2011). Audit committee gender differences and earnings management. Gender in Management, 26(7), 483-498. https://doi.org/10.1108/175424111111 75469

Warfield, T. D., Wild, J. J., \& Wild, K. L.
(1995). Managerial ownership, accounting choices, and informativeness of earnings. Journal of accounting and economics, 20(1), 61-91.

Ye, K., Zhang, R., \& Rezaee, Z. (2010). Does top executive gender diversity affect earnings quality? A large sample analysis of Chinese listed firms. Advances in Accounting, 26(1), 47-54. https:// doi.org/10.1016/j.adiac.2010.02 .008

Yunianto, A. (2013). Pengaruh Penggantian Manajemen, Dewan Komisaris Independen, Kepemilikan Managerial, Kepemilikan Institusional, dan Kualitas Audit terhadap Manajemen Laba. Jurnal Akuntansi Dan Investasi, 14(2), 143-157.

Zalata, A. M., Tauringana, V., \& Tingbani, I. (2018). Audit committee financial expertise, gender, and earnings management: Does gender of the financial expert matter? International Review of Financial Analysis, 55(October 2017), 170-183. https:// doi.org/10.1016/j.irfa.2017.11.0 02

Zehri, F., \& Zgarni, I. (2020). Internal and external corporate governance mechanisms and earnings management: an international perspective. Accounting and Management Information Systems, 19(1), 33-6. 